\title{
HAN, Byung-Chul. Sociedade do cansaço. Tradução de Enio Paulo Giachini. Petrópolis: Vozes, 2015. 80 p.
}

Geilson Fernandes de Oliveira*

*Universidade Federal do Rio Grande do Norte - Natal, RN, Brasil

Doutorando em Estudos da Mídia (bolsista Capes)

geilson_fernandes@hotmail.com 


\section{A sociedade do desempenho e suas urgências}

Cada época tem suas enfermidades fundamentais (p. 7).

É com o enunciado acima destacado que o filósofo Byung-Chul Han (1959-) abre as discussões da obra Sociedade do cansaço, uma de suas principais produções traduzidas para o português, que vem tendo ampla recepção nos círculos acadêmicos das áreas de ciências sociais e humanas no Brasil. De origem sul-coreana, mas fixado na Alemanha a partir da década de 1980, quando Han estudou Filosofia na Universidade de Friburgo e Literatura Alemã e Teologia na Universidade de Munique, o filósofo que hoje atua como docente na Universidade de Berlim é autor de uma dezena de ensaios sobre a sociedade e o ser humano.l Especificamente em a Sociedade do cansaço, o pensador promove discussões sobre as transições e reconfigurações socioculturais e suas implicações para a constituição dos sujeitos contemporâneos, dialogando com autores hoje considerados clássicos, tais como Hannah Arendt, Michel Foucault, Friedrich Nietzsche e outros.

Como aclamado pelo enunciado destacado na epígrafe, a visão do autor é de que a sociedade que vem se construindo desde o início do século XXI é bem distinta daquelas que lhe são precedentes. Segundo Han, o século passado foi imunológico, aspecto que ultrapassou a biologia e adentrou todo o social como uma forma de defesa e afastamento de tudo que poderia ser visto como "estranho". No campo biológico, os riscos de uma época viral foram suprimidos pelo aprimoramento das técnicas imunológicas, principalmente a partir da descoberta dos antibióticos, o que reduziu o medo de pandemias em todo o mundo. Já no que concerne ao social, a imunologia perde espaço quando se observa que o outro, tal como o imigrante ou estrangeiro, já não é mais uma ameaça em si, mas um peso a ser superado.

Se o século XXI já não é mais imunológico, haja vista essas questões, Han o aponta como sendo predominantemente neuronal, quando patologias de outras ordens - especialmente psíquicas - emergem e ganham espaço, tais

1 De suas obras traduzidas para o português, além da Sociedade do cansaço, temos Psicopolítica: neoliberalismo e novas técnicas de poder (Han, 2015), O aroma do tempo: um ensaio filosófico sobre a arte da demora (Han, 2016), Agonia do Eros (Han, 2017a), Sociedade da transparência (Han, 2017b) e Topologia da violência (Han, 2017c). 
como a depressão, o transtorno de déficit de atenção com síndrome de hiperatividade (TDAH), o transtorno de personalidade limítrofe (TPL), a síndrome de burnout (SB), entre outras, que passam a constituir uma "nova paisagem de enfermidades" no começo do século. Todas essas patologias, por sua vez, teriam, conforme Han, suas raízes no exagero ou imperativo da positividade, o que em sua perspectiva acaba por se configurar como uma violência, dessa vez não apenas uma violência que vem de fora, do outro, mas que tem as suas origens no igual e até em si mesmo.

Com base nos escritos do autor, observam-se como vetores dessa violência aqueles discursos que colocam o sujeito como detentor de todos os poderes sobre si mesmo, mensagens que pregam seu direito a felicidade e bem-estar em todas as esferas da vida, enunciados que propagam o poder de se ser quem se quer ou poder ter tudo aquilo que se deseja de forma ilimitada. Melhor dizendo, o poder de poder ad infinitum. Todavia, como tipo ideal de uma sociedade que preza pelo sem limites, a sua impossibilidade logo bate à porta, momento no qual frustrações irrompem e desencadeiam patologias não só naqueles que percebem a partir da experiência o quão intangível o poder de poder tudo é, mas também nos indivíduos que simplesmente não se veem em tais pressupostos, que passam a se sentir igualmente deslocados.

A positivação imperativa do mundo que dá base à sociedade contemporânea coloca-se como uma normalidade a ser seguida. $O$ que antes era tido como suficiente, agora já não mais o é, e superar-se continuamente constitui-se como como uma ética. Dessa forma, qualquer sentimento ou emoção de ordem negativa logo são interditadas, quiçá excluídas, visando a maximização do desempenho. Produz-se, assim, um modo de vida que desconsidera a potência produtiva da raiva, tristeza, desamparo e outros estados de ânimos vistos pelo viés do desempenho como negativos para a produção dos sujeitos.

A passagem de patologias de origem bacteriológicas superadas pela imunologia para as patologias neuronais indica que as transformações tecidas e expressas no contemporâneo estão além das sociedades disciplinares caracterizadas por Foucault (1987). Fortemente marcadas pelo não poder, esse modelo de sociedade produzia doentes, loucos, presos entre muitas outras formas de subjetividades que eram atravessadas pela negação da normalidade. Hoje, segundo Han, vive-se na sociedade do desempenho. Nesse sentido, ao invés das prisões, hospitais, fábricas e manicômios, se tem academias, shoppings 
centers, bancos e laboratórios de genética que afirmam o potencial dos sujeitos na produção de si mesmos, objetivando comportamentos cada vez mais bem-sucedidos e satisfatórios.

Esses não são mais sujeitos da obediência, como os da sociedade disciplinar, mas sujeitos de si mesmos, do desempenho e da (auto)produção. Nesse modelo de sociedade, "no lugar de proibição, mandamento ou lei, entram projeto, iniciativa e motivação" (p. 24). É justamente aí que o discurso de poder ilimitado entra em cena, já que o indivíduo é um empreendedor de si mesmo, metáfora que dialoga de modo direto com o regime neoliberal, no qual o self-mad man (o homem que faz a si mesmo de modo contínuo) é sua figura ideal-típica. É válido ressaltar que o sujeito do desempenho não deixa de ser disciplinado, no entanto, trata-se de uma autodisciplina, o que não propriamente implica liberdade. O pressuposto do desempenho e da autodisciplina também diz respeito à autoexploração e sua premissa de resultados cada vez mais exitosos para o próprio sujeito - o que não deixa de render bons frutos para o mercado capitalista neoliberal. Com efeito, "o explorado é ao mesmo tempo o explorador. Agressor e vítima não podem mais ser distinguidos" (p. 30). Com uma outra configuração social, outras patologias surgem: agora não mais loucos e delinquentes, mas depressivos e fracassados.

As afirmações do filósofo são categóricas e possuem fundamento explicitado, já que conforme pesquisas recentes (Depressão..., 2017) o número de indivíduos com depressão ou outras doenças de origem psicossomáticas (ansiedade, estresse, mudanças abruptas de humor, bipolaridade, etc.) tem crescido a cada ano, o que é contraditório e sintomático de um tempo histórico em que a positividade é tão reverberada. Refletindo sobre a depressão, o autor indica que ela não é tão somente uma expressão categórica do fracasso do homem em ser ele mesmo, como postulou Alain Ehrenberg (2008), mas resultante das pressões de desempenho. "A lamúria do indivíduo depressivo de que nada é possivel só se torna possível numa sociedade que crê que nada é impossível" (p. 29, grifo do autor), argumenta o filósofo.

Sendo profundamente marcado por esses pressupostos, o ethos da sociedade do desempenho pressupõe a multitarefa como um ganho exponencial para os sujeitos. E isso é apreendido pelas crianças desde cedo, já que muitas, além do horário escolar normal, também fazem cursos de natação, música, línguas, etc., com vistas a uma "melhor formação e preparo" para o futuro, onde por 
esse viés deverão ter sucesso em todos os âmbitos de suas existências. Na vida adulta, a multitarefa se aperfeiçoa, tornando-se adjetivo utilizado para definir sujeitos proativos. Não raro, há casos em que indivíduos veem seriados ou filmes, se alimentam e trocam mensagens ao mesmo tempo, enviam e-mails ou atendam telefonemas e ainda conversem sobre o dia de seus filhos pequenos enquanto dirigem, trabalhem ao mesmo tempo em que ligam para casa para saber se está tudo ok, além de ficarem também atentos aos assuntos discutidos por amigos com os quais partilham o ambiente de trabalho, entre muitos outros exemplos que desvelam mudanças radicais no que concerne à economia da atenção. Fazer uma única coisa de cada vez, dessa forma, é tomado como uma limitação, característica factível daqueles que não conseguem atingir um bom desempenho. Han, entretanto, afirma que a multitarefa não apresenta nenhum progresso civilizatório, mas um retrocesso, uma vez que consiste em uma atitude habitual de animais em estado selvagem, os quais necessitam atentar para diversos aspectos ao mesmo tempo para manter a sua sobrevivência, como acontece com aqueles que ao se alimentarem têm de ficar atentos ao que ocorre ao redor para não ter seu alimento tomado ou se tornarem comida devido à falta de atenção (p. 31).

Com a multitarefa se tem uma outra forma de atenção, a qual na visão do autor se torna mais dispersa conforme a quantidade de atividades e processos simultâneos em curso. Ademais, a multitarefa implica para o indivíduo pouco espaço para o tédio, sobretudo aquele de ordem criativa, considerando que a pura inquietação não gera nada de novo. Outrossim, esse tipo de ação também induz a redução da capacidade contemplativa, já que o sujeito está pretensamente sempre atento a tudo que acontece à sua volta, mas sem nenhum olhar mais aprofundado e reflexivo. É a partir desse ponto que Han mobiliza o pensamento desenvolvido por Arendt (2001) sobre a vita activa, pois, para a autora, todas as formas de ação do sujeito decairiam ao patamar do trabalho, fazendo do homem um animal laborans que deixa de lado a vida contemplativa. Contudo, Han apresenta uma visão contrária a essa perspectiva, haja vista que na sociedade do desempenho o homem não abandona seu ego para entregar-se ao trabalho, apesar deste o acompanhar e por vezes se estender ao espaço da casa e do lazer. O sujeito do desempenho, segundo ele, é tão ativo e atento a si mesmo - e não somente ao seu trabalho - que a falta do ser enquanto instância criativa faz surgir nervosismos e inquietações. 
Uma vida ativa que considere a necessidade de espaço para o tédio e a contemplação, de todo modo, se torna imprescindível em uma sociedade em o que o poder tudo é uma realidade e tem como um de seus efeitos a frustração. É por meio do tédio que se abre espaço para o novo, limitando a mera reprodução. Contudo, saber e poder entediar-se tem se tem mostrado como um desafio em uma configuração social em que essa ação é tida como improdutiva. O mesmo acontece com a vida contemplativa. O sujeito do desempenho até pode ter acesso a lugares ou objetos que possuam como finalidade puramente a contemplação, o que não quer dizer que ela ocorra. A diferença está no fato de que, como aponta Nietzsche (2005, p. 51), aprender a ver significa "habituar o olho ao descanso, à paciência, ao deixar-aproximar-se-de-si", com vistas a capacitar os modos de ver com uma atenção profunda e cuidadosa, o que não ocorre frente às atribulações das ações sempre imediatistas da sociedade do desempenho. Uma outra pedagogia do olhar se impõe como contraponto a esse estado de coisas, pois a mera ação por si mesma nada acrescenta, conforme assinala Han.

Todos esses aspectos convergem e corroboram a percepção de que, uma vez detentores de tanto poder - e por isso mesmo tão cobrados - os sujeitos da sociedade do desempenho têm suas subjetividades e sociabilidades atravessadas pelas premissas de êxito e positividade. Porém, com modelos tão bem demarcados e assim convocados, não é de se estranhar que logo apesentem frustrações e patologias. É daí que surge o pressuposto de que a sociedade do desempenho é também a sociedade do cansaço. Com a necessidade de uma vida cada vez mais ativa, há o esgotamento dos sujeitos e de suas forças. Se o tédio e a vida contemplativa nessa sociedade não têm espaço, muito menos o tem o descanso, elemento a ser superado de acordo com o ethos dessa formação social plena de urgências, mesmo que para isso tenha que se recorrer ao doping. Assim, se tornam corriqueiros o uso de medicamentos com vistas a se superar o esgotamento, mesmo que possibilite um desempenho sem desempenho (p. 69).

A sociedade do desempenho estabelece modos de vida que se expressam por um excesso ou tirania da positividade, produzindo sujeitos que devem buscar sempre superar-se com relação aos seus ganhos. Com isso, são engendradas subjetividades e sociabilidades agenciadas pela multitarefa e constante (auto) produção. Inversamente, esses pressupostos têm gerado, contudo, culpas e 
frustrações, mecanismos de sofrimento que vêm desencadeando patologias neuronais diversas, uma vez que os modelos impostos não são factíveis em sua realização. Ao invés de sujeitos com desempenhos sempre crescentes, as cobranças resultam num cansaço psíquico que induz a doenças muitas vezes difíceis de serem superadas, já que continua a ser propagado o preceito de que o normal seria idealmente aquele desempenho uma vez já não alcançado. $\mathrm{Na}$ sociedade do desempenho os sujeitos estão, assim, fadados a falharem.

O olhar atento e cuidadoso de Han sobre essas questões, apesar de indicar certo pessimismo traduzido na ausência de saídas concernente a esse estado de coisas, se mostra profícuo para se refletir sobre os modelos de sociedade que estão se construindo, sobretudo as que têm suas bases fundadas nos sistemas de trocas capitalistas, bem como sobre os sujeitos e as subjetividades que lhes são inerentes, levantando uma questão de suma importância: ao se entregar aos postulados do desempenho e suas urgências o sujeito pode deixar escapar o olhar necessário sobre si mesmo.

\section{Referências}

ARENDT, H. A condição humana. Lisboa: Relógio d’Água, 2001.

DEPRESSÃO cresce no mundo, segundo OMS; Brasil tem maior prevalência da América Latina. G1. Bem Estar, 23 fev. 2017. Disponível em: <https://g1.globo.com/ bemestar/noticia/depressao-cresce-no-mundo-segundo-oms-brasil-tem-maior-prevalencia-da-america-latina.ghtml >. Acesso em: 27 fev. 2017.

EHRENBERG, A. Das erschöpfte Selbst: Depression und Gesellschaft in der Gegenwart. Frankfurt: Campus, 2008.

FOUCAULT, M. Vigiar e punir: nascimento da prisão. Trad. Lígia M. Ponde Vassalo. Petrópolis: Vozes, 1987.

HAN, B-C. Psicopolítica: neoliberalismo e novas técnicas de poder. Lisboa: Relógio d'Água, 2015.

HAN, B-C. O aroma do tempo: um ensaio filosófico sobre a arte da demora. Lisboa: Relógio d'Água, 2016.

HAN, B-C. Agonia do Eros. Petrópolis: Vozes, 2017a.

HAN, B-C. Sociedade da transparência. Petrópolis: Vozes, 2017b. 
HAN, B-C. Topologia da violência. Petrópolis: Vozes, 2017c.

NIETZSCHE, F. Humano, demasiado humano. Tradução, notas e posfácio: Paulo César de Souza. São Paulo: Companhia das Letras, 2005. 